\title{
What Liberal Delusions About Conservatism Teach
}

\author{
James M. Ault, Jr.
}

Published online: 3 December 2011

(C) Springer Science+Business Media, LLC 2011

In 1987, a generation ago, when my documentary film about life in a fundamentalist Baptist church appeared on PBS, I remember telling liberal colleagues in academia and documentary filmmaking that I was beginning to write a book on that project that would help us better understand new right conservatism. "That's great!" they'd say encouragingly, "We need that! But," they would often add, trying to be helpful, "you'd better get it out quickly"- that is, before such conservatism would vanish from American life.

Yet, within seven short years, by 1994, the Republican Party, made-over from the bottom up by such "pro-family" social conservatism, would seize control of both houses of Congress for the first time in 45 years. And 10 years later, when liberal Democrats found themselves stunned again by George W. Bush's re-election as President accompanied by swelling Republican majorities in both Houses of Congress, it was Phyllis Schlafly, the conservative Catholic antifeminist whose Eagle Forums helped mobilize such conservatism in the first place, who was said to be the second most powerful person shaping the platform of the Republican National Committee that year. A conservative "pro-family" movement, once seen as extremist and marginal, had come to the fulcrum of national power.

Now, a generation later, in March 2011, as political analysts in CNN's "Situation Room" debated the Tea Party's emerging threat to Democrats in upcoming elections, David Gergen stopped his colleagues short to remind

\footnotetext{
${ }^{1}$ Born Again: Life in a Fundamentalist Baptist Church, produced and directed by James Ault and Michael Camerini, appeared as a national prime-time special on PBS in 1987. Distributed by James Ault Productions, www.jamesault.com.
}

J. M. Ault, Jr. $(\bowtie)$

James Ault Productions,

P.O. Box 493, Northampton, MA 01062, USA

e-mail: contact@jamesault.com them that just 2 years before, in that very same room, in the wake of Obama's presidential victory, they had all been discussing the passing of such conservatism from American politics.

"Isn't there a pattern here?" we have to wonder-a pattern of persistent misperception, of the liberal intelligentsia's recurring misreading of such conservatism's popular appeal to its fellow Americans? It reminds me of a distinguished historian of American fundamentalism once remarking that ever since Christian fundamentalism's rise to national prominence in the $1920 \mathrm{~s}$, commentators have been routinely predicting its "imminent demise."

\section{Why Liberals Misread Popular Conservatism}

The liberal intelligentsia's persistent misreading of the popular appeal of such movements, I would argue, rests on a culturally induced failure to understand even the very meaning of their basic tenets to those who embrace them. Liberals remain baffled, to take one example, by how conservatives so untroublesomely connect right-to-life with support for militarism - to connect pro-life with pro-war. They often see this illogical pairing (in their eyes) simply as a sign of conservatives' hypocrisy or bad faith. ${ }^{3}$

For their part, conservatives would be bewildered that liberals could think this pairing does not make perfect sense. "I was always puzzled by liberals' positions on things," confessed a student at the fundamentalist theological school of Bob Jones University, when he wrote to thank

\footnotetext{
${ }^{2}$ Ernest Sandeen, The Roots of Fundamentalism: British and American Millenarianism, (Chicago: University of Chicago Press, 1970). p. ix

${ }^{3}$ For instance, see James M. Ault, Jr., Spirit and Flesh: Life in a Fundamentalist Baptist Church. (NY: Knopf, 2004), p. 100ff
} 
me for my book, Spirit and Flesh: Life in a Fundamentalist Baptist Church, when it appeared. "I simply chalked them up to the fact that they weren't saved," he admitted. "Now I realize that there are more proximate causes," he reflected gratefully, "and find I am able to be more tolerant of them." While pervasive misunderstanding plagues both sides in the bitter "culture wars" so often paralyzing our nation, I am mainly addressing in this article for an academic journal those of the liberal intelligentsia.

Liberals also have trouble understanding why conservative women, who make up sizable majorities in the right-tolife movement and in fundamentalist churches, insist that men are "heads of the home" or "heads of the church". Or, why social conservatives feel gay marriage actually threatens family life.

They have trouble understanding what conservatives mean when they say things like "Obama's a socialist and socialism is destroying our country." Those dismissing such a damning charge as racist have to recognize that the same things were said about white liberal Democrats like Ted Kennedy in the Moral Majority Era. "Ted Kennedy's a communist," they would say, "and communism is undermining the moral fiber of American life."

By "communism" or "socialism," of course, American conservatives generally do not mean Leninism or Maoism as practiced in Russia or China, but simply "Big Government"- that is, meeting needs and solving problems through bureaucratically delivered government programs. The specter of "Big Government," now focused on by Tea Party activists from the store of new right enthusiasms, has galvanized the political force of a new generation of conservatives. Yet, liberals ask in puzzlement, why should government programs-some helping poor families, of course - be seen to undermine "the moral fiber of American life," or threaten the family? Liberals' puzzlement around such basic tenets of new right conservatism points to deeply rooted sources of America's "culture wars." They involve basic failures of understanding.

\section{Understanding Popular Conservatism}

I came to realize this during three years field research among grass-roots "pro-family" conservatives in the "Moral Majority" era of the 1980s. As a sixties radical who had been involved in anti-war work, commune-living and what we then simply called "the women's movement," I spent time, like an anthropologist, hanging out with right-tolifers, home-schoolers, and parents campaigning against sex-education, before settling in to study a fundamentalist Baptist church outside Worcester, Massachusetts. Shawmut River Baptist Church, as I call it in my book Spirit and Flesh, was the kind of grass-roots church then at the cutting-edge of new right movements on their way to transforming American politics. Its pastor and founder, an early graduate of Jerry Falwell's Liberty University, was Vice President of the Moral Majority in Massachusetts. ${ }^{4}$

But, the range of "pro-family" conservatives I met during my research included Catholics, Jews, and Mormons, as well as other kinds of Protestants, and those with no religion at all. That conflicts over family-value issues cut across all religions in American life-even evangelical Christians have partisans on both sides-shows that we cannot explain such differences in terms of any particular religious ideas or practices, like literal readings of the Bible or the Torah, for instance. Something else must be at work and I was interested to understand what that "something else" was.

During my first few months at the Shawmut River Baptist Church the strain of simply trying to understand members' conversations and not say something offensive, thereby identifying me as their enemy in the bitter culture wars raging at the time, routinely gave me headaches. But, over time, as my understandings grew, I found that I could, at times, even during heated political discussion, finish their sentences. $^{5}$

I learned that I could better understand conservatives I met by considering the social world I found them in-a world far different from the one I shared with liberal friends and colleagues. For example, all the conservatives I studied came of age - or at that time lived-within a circle of extended-family relations they relied on day-in-day-out to cope with the daily challenges of life. Their relations of mutual support worked through family obligations governed by the ethic of reciprocity - just as you have received so are you obliged to give, and just as you give, so shall you receive, in law-like movements of a cosmos in which, as the folk saying goes, "what goes `round, comes 'round." Extended families were the building blocks of the fundamentalist congregation we filmed (as in Jerry Falwell's own congregation). I remember noticing among Shawmut River's hundred-so congregants that virtually all its single members,

\footnotetext{
${ }^{4}$ Ibid., Ch. 1

${ }^{5}$ Ibid., pp. $66-68$

${ }^{6}$ Ibid., p. 95 ff. The importance of extended-family ties is reflected indirectly in demographic data surfacing after the presidential elections of 2004. The most consistent demographic difference, it was noted, between "red" (conservative) and "blue" (liberal) states or regions was that those in the "red" areas had more children and had them earlier than those in the "blue," an essential ingredient in creating cross-generational extended-family life. Cf. David Brooks, "The New Red-Diaper Babies," The New York Times, Dec. 7, 2004. Similar demographic differences stood out between pro-life and prochoice supporters in the best study of conflicts over abortion. Kristin Luker, Abortion and the Politics of Motherhood (Berkeley: University of California Press, 1984), p. 196
} 
even into their late thirties, if they remained unmarried, still lived "at home" - that is, with their parents.

In such a world, where people depend on family helping out even when it is inconvenient or their own resources are wearing thin, opposition to abortion and support for militarism can be seen quite sensibly to go hand in hand. Both represent family obligations of an ultimate kind: for women, to risk their lives and sacrifice to bear and care for children and other dependents, even when it isn't convenient to do so; and for men, as one of the requirements of male honor, to take up arms and sacrifice their lives for family and country - and, most immediately, for "brothers" in their unit (even in a war they do not choose or approve). In these idealizations stirring the highest passions, obligations to family and community appear not as matters of choice but of unquestionable duty. At times, conservatives make such underlying, taken-for-granted connections explicit, as in the slogan often used in the right-to-life movement at that time: "If life isn't safe in the womb," activists would point out grimly, "it isn't safe in the nursing home!"7

The cultural moorings of such commitments to family obligations - always under pressure from the restless geographic and social mobility characteristic of American life-were challenged powerfully by the cultural tsunami of the '60's and '70's: by its watchwords to "do your own thing" or "never trust anyone over 30 ," by championing the rights of women to have a career outside the home as an end in itself or to abort an unwanted child, or by encouraging such moral revulsion against war, in general, that protestors were emboldened to spit on soldiers returning from service in Vietnam. These were moral enthusiasms carried often by highly educated, prestigecarrying strata in American life. The women of Shawmut River felt sixties feminists, to take one example, devalued their primary identity as housewives and mothers and made them look stupid. They felt the need to fight back. ${ }^{8}$

Consider also the charge that "socialism (or Big Government) is undermining the moral fiber of American life." If conservatives have in mind, for instance, liberals' vision of extending the welfare state as a truly effective safety net all citizens can rely on as a matter of individual right, would that not mean that people would not have to depend as much on other means to survive, like family? And if the belief that you will eventually need to depend on family helps motivate you to make sacrifices for family members now, isn't it sensible to believe that such a welfare state - or Big Government, in general - stands to undermine some underpinnings of that ethic of reciprocity, or the moral fiber of American life as you know it? Indeed, the ethic of reciprocity itself - a reason

\footnotetext{
${ }^{7}$ Spirit and Flesh, p. $100 \mathrm{ff}$

${ }^{8}$ Ibid., p. 257
}

many Americans give for their community service, "to give back" to their community - can be felt to be negated by an impersonal bureaucracy giving someone material support simply as a naked right, with no obligations attached - that is, as an "entitlement."

Such assumptions help infuse conservatives' critique of Big Government with its heavy moral condemnation, shared by social conservatives and current Tea Party activists alike. ${ }^{10}$ All the social conservatives I studied in the 1980s whom I recently contacted for this article, applaud the current Tea Party movement for carrying forward important elements (if not all) of their own activism a generation before. These are not discrete, episodic political movements, then, but share common roots and common meanings among broad swaths of the American public.

Furthermore, for social conservatives, the "law of reciprocity," seen as an essential part of how the cosmos works, also underlies their support for capital punishment and, among Christians, for their preferred theology of "substitutionary atonement"- that is, that Jesus' death on the cross was a necessary sacrifice to pay the price for all humanity's sins. According to this commonly held doctrine, payment for $\sin$ is seen as such an inescapable part of the cosmos that even Gold Almighty could not breach it, having to give up the life of his one and only son to redeem humanity from their sin.

Reciprocity is also reflected from another angle, in the Golden Rule, "do unto others as you would have them do unto you," that Jesus is said to have commended to his disciples as the commandment that "sums up the Law and the Prophets" (Matthew 7:12). The obligation to help, as part of this ethic of reciprocity, was so deeply writ in the social consciousness of members of Shawmut River Baptist Church, that I began to notice while doing fieldwork among them, that as soon as I entered the Worcester area, driving from my home an hour away, I felt safer. I knew that if my car broke down or anything happened, church members would not hesitate to come help me out.

In these ways, such pro-family enthusiasms - which are, above all, what has given new right conservatism its popular appeal and, therefore, political clout — can be seen as more sensible, coherent, and even positive, in the context of lives lived through extended-family ties. And it is the importance of such ties that connects blue-collar conservatives around issues of "family values" with the propertied upper class (like the Bush clan), whose lives are also

\footnotetext{
${ }^{9}$ Similar sentiments among conservatives arose in England in opposition to the 19th century "poor law." Cf. Gareth Stedman Jones, Outcast London (Baltimore: Penguin Books, 1971), pp. 251-3

${ }^{10}$ The burden bureaucratic government regulations place on small business rather than large corporations is, of course, another important practical source of popular sentiment against Big Government. Spirit and Flesh, p. 326.
} 
organized through extended-family ties, often congealing around family fortunes. It also connect them with the growing number of Hispanic voters who have shown themselves responsive to Republicans' conservative profamily appeals - and, on certain issues, like homosexual rights and abortion, with traditionally Democratic African Americans, as well.

Extended-family ties typically provide the backbone of small, family-based businesses or enterprises. The ideal of small business-a goal American wage earners have historically aspired to and identified with - has a striking prominence in the ideological discourse of conservative movements in American life, including the current Tea Party. More concretely, we might notice how often conservative churches, and the broader institutions they spawn, take the form of family-based enterprises in which leadership and authority are held and passed down through family, even across several generations. Consider Bob Jones University, for instance, now, over three generations since its founding in 1921, headed by Bob Jones III, or Jerry Falwell's Liberty University, now headed by one son, Jerry, Jr., while his megachurch, Thomas Road Baptist, is now headed by his younger son, Jonathan. ${ }^{11}$

In such family-based, dynastic institutions, like kingship, family is not separate from enterprise or firm, but, instead, provides the building blocks for organizational life. ${ }^{12}$ For that reason, women, within their traditional roles as keepers of home and family, are not separated from the levers of institutional power, but, instead, have privileged access to them through the very sinews of family relationships where they enjoy their traditional "place." If men traditionally wield formal authority, on an individual basis - as family head, chief, king or CEO-women have collective influence and force within the dense network of family relationships involved. As in ancient kingships, such collective powers are usually indirect, if not subliminal. "The man's the head," Sharon Valenti, wife of Shawmut River's founding pastor once quipped about the realities of men's headship in family and church. "The woman's the neck that turns the head," she concluded wryly. Recognizing the substantive powers that women wield in such contexts helps us understand why such women, instead of challenging traditional gender roles in the family, tend to defend them.

Of course, the felt need to defend tradition in family life, or to defend family obligations as a way of life, would arise only when people feel they are under attack, or otherwise challenged or undermined. The extraordinarily high rates of

\footnotetext{
$\overline{11}$ From institutional websites.

${ }^{12}$ When Bob Jones III studied history at Notre Dame, one teacher noticed that he took particular interest in studying the dynamics of the "Mather dynasty" (Cotton Mather et al.) in colonial Massachusetts. Personal communication, George Marsden.
}

geographic and social mobility in the United States, compared to other advanced industrial societies, represent such corrosive forces, in the first place, and help explain why politics around such family-value issues are a distinctly American phenomenon to begin with. They are not found, for example, in Spain, Holland, Japan, or other advanced industrial nations, whose citizens are apt to look at American battles over things like abortion or school prayer as the bizarre obsessions of some strange tribe. Likewise, the cultural tsunami of the sixties as it bore down on traditional gender roles in the family, was a much greater popular force in the United States than in other advanced industrial nations.

The felt need to defend tradition in family life tends to arise, then, among people who feel that their reliance on familybased networks of mutual support is being undermined or under attack. That might be the case for rural migrants to the city, for instance, who have historically provided the seedbed for fundamentalist Christianity in America, or for residents of small towns overrun by suburban sprawl. But it would not be so, say, for members of a rural community untouched by urbanization. When pitched battles between conservatives and liberals were raging in the Southern Baptist Convention in the mid-1980s, for example, an anthropologist studying an isolated rural community in South Carolina found that members of its local Southern Baptist church had to have a special envoy sent out to them from the central church offices to explain what these family-value conflicts were all about to begin with! ${ }^{13}$

Many white academics deny the very existence, or significance, of extended-family ties in contemporary America, even though their presence continually shows up in data of various kinds - for instance, in reliable data on who cares for preschool children when their parents are working. While $45 \%$ of parents in America rely on grandparents or other relatives regularly for such helpthat means on a daily basis, week-in, week-out — only $30 \%$ use all preschool, kindergarten and daycare facilities combined. ${ }^{14}$ A telling observation about urban sociology in America is that, ever since its founding by the Chicago School at the beginning of the $20^{\text {th }}$ century, positing that city life would see "primary groups," like families, be replaced by voluntary associations, its practitioners have spent the past century repeatedly rediscovering the family's importance. ${ }^{15}$

\footnotetext{
${ }^{13}$ Cf. Spirit and Flesh, p. 105-9, citing M. Jean Heriot, personal communication. This also helps explain why fundamentalist Christianity was not a rural phenomenon, but arose first in the new industrial cities of America-Boston, New York, Chicago and Los Angeles, for example - and why it does not come to the South until after World War II, and then to New South cities like Lynchburg, Charlotte and Virginia Beach.

${ }^{14}$ Kristin Smith, Who's Minding the Kids? Current Population Reports, P70-70. U.S. Census Bureau, Washington, DC, 2000, p. 5

${ }^{15}$ Spirit and Flesh, p. 382n
} 
A key reason for this perennial blindness, as well as liberals' and conservatives' persistent failures to understand one another, is that family life - where we begin and end each day-has a taken-for-grantedness that often makes it difficult to notice, let alone take account of. We simply assume it in what we say, do, think, and even perceive. I remember Frank Valenti, the then young pastor of Shawmut River Baptist Church, for example, turning to me one day, after knowing for over a year that I, a single man in my thirties, lived an hour's drive away in Northampton, Massachusetts, while my parents lived in Pittsburgh, Pennsylvania. Yet, he asked me one afternoon with a puzzled look, "Where do you live out there in Northampton anyway? You're still at home, aren't you?" (meaning with my parents).

Such a naive projection of his own assumptions about family life reminds me how an academic reviewer of our documentary film Born Again could blindly attribute the plight of an alcoholic man we portray - whom we show in his home one evening resisting the weekly pressures from his younger brother and nephew to see him "get saved"- as suffering from "social isolation." Or how filmmakers like Bill Moyers and his team could show in their award-winning documentary The Vanishing Family, a young AfricanAmerican mother with her baby and own mother sitting on the stoop of the apartment building where they all lived together, as an example of the frightening trend of "single women . . . raising children alone." 16

My research at Shawmut River and with other conservatives I met, convinced me how different their lives were from those of my friends and colleagues in the liberal intelligentsia. As college-educated professionals, we generally prepared, from the moment we left home for college, to leave family dependencies behind and learn to live as selfgoverning individuals. Growing up without a circle of relatives around to help with childcare and other needs, we often saw our own mothers stuck at home alone with us children with no one to turn to for support or sanity. They were living examples of the plight of the white suburban housewife portrayed in Betty Friedan's memoir, The Feminine Mystique, a book that helped launch sixties feminism. The basic organizational form sixties feminism took, the small "consciousness-raising" or "support" group, addressed those very needs. However, it would have been redundant, or certainly not a felt need, for the women of Shawmut River or other conservative groups I studied.

What defined sixties feminism as a movement, according to its leading interpreters, was that it did not simply call for equality in public life-like equal pay for equal work or the right to vote - but, instead, for equality in the private sphere of family and personal life. ${ }^{17}$ It proclaimed having a career

\footnotetext{
$\overline{16}$ Ibid, p. 329, p. 113

${ }^{17}$ Ibid, pp. 10-11
}

outside the home as every woman's right. In the absence of relatives around to help out, controlling the burdens attending the birth of a new child assumed greater importance, if not urgency. And traditional gender roles had to be modified, or dispensed with; husbands had to step up to share housework and childcare and wives step outside the family into roles, as individuals, in public life.

Indeed, the very absence of family relationships to turn to for help puts pressures on marriages to become joint partnerships in handling the responsibilities of family life, rather than abiding by the traditional model of husband and wife occupying "separate spheres" requiring little or no coordination. Such "companionate marriages," as they came to be called, require more communication, more sharing, and greater intimacy between husband and wife. Sex in marriage, rather than being simply a means of procreation that one can either enjoy or live without - a traditional blue-collar and aristocratic view - took on greater importance, especially in the modern middle class, as a vehicle for emotional intimacy and an expression of romantic love. ${ }^{18}$ Such changes place increased demands on marriage, producing considerable strain and instability. Sexual pleasure, the great sociologist Max Weber once observed, is inherently unstable as a foundation for social relationships. ${ }^{19}$ In an era calling for both women's liberation and sexual liberation, such challenges led to skyrocketing rates of divorce in post-sixties America-and to its commanding lead as the nation having the world's highest divorce rate. ${ }^{20}$ It also put a greater premium on "trying out" such a challenging, delicately balanced relationship before marriage.

Furthermore, turning to another dimension of such changes, the increased importance of sexual intimacy in modern middle-class marriages makes the couple relationship all the more sensitive to the sexual orientation of partners. If a spouse has any homosexual proclivities - for whatever reasons, I might add - marriages requiring greater intimacy and sex as a vehicle for that intimacy will just not work as they often did traditionally.

At the same time, facing homosexuality matter-of-factly as a legitimate reality, is especially challenging, if not threatening, where extended-family ties prevail, creating separate "worlds" for men and women in which same-sex solidarities and identities flourish. I mean here everything from the bluecollar pattern where a wife and mother might rely for help at

\footnotetext{
$\overline{18}$ Ibid., p. 393n. Cf. Helen Horowitz's account of the growth of new models of marriage involving romantic love in $19^{\text {th }}$ century America carried largely by urban professions. Helen Lefkowitz Horowitz, Rereading Sex: Battles Over Sexual Knowledge and Suppression in Nineteenth-Century America (NY: Alfred Knopf), 2002.

${ }^{19}$ Max Weber, Economy and Society, vol. 2 (NY: Bedminster Press, 1968), p.604

${ }^{20}$ See, for instance, Betsey Stevenson and Justin Wolfers, "Marriage and Divorce: Changes and their Driving Forces," Journal of Economic Perspectives - Volume 21, Number 2-Spring 2007-Pages 27-52
} 
home on her own mother (or other women kin) while her husband hangs out with guys at the shop or in his pick-up truck, to inner city gangs formed on "brother" or "sister" solidarities, or to churches like Shawmut River where the men's prayer breakfast was a mainstay of church life. In such "separate spheres" or separate worlds, men and women are seen - and, indeed, become - different creatures that find it hard to understand "the other." "Women! Go figure!" was the kind of comment one heard routinely in men's talk at Shawmut River. And I remember one church member recounting to me frankly her oppositional attitude toward men as she contemplated marriage. "Once you've got one," she remembers thinking to herself, "see what you can get from him!",21

In all such settings same-sex ties often trump couple relationships between a woman and a man. In inner city gangs, for instance, a fight between two women competing for the same man can decide who gets him. The man's will doesn't even count in the matter! More striking examples would be arranged marriages, or the weight wider families play in marriage, in Asia or Africa, where extended families often play vital roles even among the most urbane city dwellers.

In much of sub-Saharan Africa, for instance, men and women usually sit separately at church or public meetings. In Ghana, in West Africa, men walk hand-in-hand with one another freely on the streets, sharing physical affections of a purely fraternal kind. Similar kinds of physical affection, of a rough and tumble variety, might be found in the fraternity of blue-collar American men out deer-hunting or fishing together for weeks at a time. In such contexts, legitimizing homosexuality —or saying, for instance, "Isn't it great that we can marry each other?" rather than having to deal with "those women" (or "those men") - tends to be particularly threatening. It stands to short-circuit the very need to embrace "the other" to produce new families. In such contexts, then, does it not make sense that homosexual marriage might be felt to threaten family life? And what might be the consequences, say, of encouraging an openness toward homosexuality among inner city African-American or Latino teenagers organized in same-sex gangs?

When issues of homosexual rights are pressed by liberal activists as absolute matters of social justice, there seems to be no consideration of the different challenges they might pose in settings where the very place and role of sexuality in family and society might differ so radically. Opponents of same-sex marriage are dismissed with disdain simply as hopeless homophobes. In this context, it seems relevant to bear in mind that the very word "homosexual" is a relatively recent invention, arising only in the late $19^{\text {th }}$ century, and, then, in the highly urbanized industrial societies of the West.

\footnotetext{
${ }^{21}$ Spirit and Flesh, p. 248. For a fuller account of gender, sexuality and marriage in a fundamentalist Baptist community, see Ch. 16.
}

When homosexual rights have been pressed in Africa, to shift our considerations to the world stage, where similar moral-political conflicts have been stirred, they have routinely run into stubborn resistance. The continued unraveling of the Anglican Communion stemming from such conflicts at its Lambeth Conference in 1998 is evidence of the destructive paths such conflicts can take. ${ }^{22}$ Western commentators sometimes attribute the powerful opposition to homosexuality found in most of sub-Saharan Africa to Christian growth there, and to the presumed influence of conservative Christians from the United States. However, the sense of homosexuality as anathema is deeply embedded in most local cultures in Africa and prevails there among Muslims, as well as Christians, and among those practicing traditional religion or no religion at all. ${ }^{23}$

\section{On the World Stage: The Case of African Christianity}

The continuing travails of the Anglican Communion represent just one kind of conflict that might erupt from tensions in the relationships between liberals in the West and the increasingly dominant branches of Christianity now in Africa and other parts of the global South. Christianity's explosive growth in Africa, I have learned from an extensive documentary film project on the subject I have been directing over the past decade, is not a result of the mission work of foreign churches from America or the West, as many assume. Instead, it is mainly a result of Africans rooting Christian faith more authentically in their own cultures - that is, "contextualizing," "indigenizing" or "Africanizing" it. ${ }^{24}$ Above all, this has meant shedding western forms of Christianity shaped by the European

\footnotetext{
$\overline{{ }^{22} \text { After African }}$ and Asian bishops played a critical role in defeating measures to accept homosexual practice in the Anglican Communion at its decennial Lambeth Conference in 1998 and the Episcopal Church USA went on to ordain an openly gay bishop in 2003, dissenting congregations in the United States and Canada withdrew from the Episcopal Church (and from the Anglican Church of Canada) and formed the Anglican Church in North America, putting themselves under the authority of Anglican bishops from Nigeria, Uganda, Kenya and Rwanda. The ACNA now has roughly 100,000 members in over 680 parishes across North America. http://en. wikipedia.org/wiki/Anglican_Church_in_North_America and www. anglicanchurch.net/?/main/locator/us

${ }^{23}$ That South Africa is an exception here, showing greater tolerance for homosexuality, makes sense because of its cultural development as a more urban, industrial society.

${ }^{24}$ This documentary film project on African Christianity was initially funded by Pew Charitable Trusts and sponsored by Hartford Seminary. With guidance from leading scholars on the subject, like Andrew Walls and Kwame Bediako, it explores developments in two nations in sub-Saharan Africa, Ghana and Zimbabwe. Two films from this project are nearing release: African Christianity Rising: Stories from Ghana and Stories from Zimbabwe. James Ault Productions, Northampton, Massachusetts. www.jamesault.com
} 
Enlightenment that imagined a thoroughgoing separation of material and spiritual worlds. Most Africans, by contrast, hold worldviews assuming, instead, thoroughgoing interaction between material and spiritual worlds, and the latter made up of spirit entities of various kinds. To root their faith in local cultures and worldview, then, African Christians have routinely embraced healing, prophesy, exorcism and the experience of God in physical, bodily ways. They see and experience the supernatural at work around them routinely in daily life. ${ }^{25}$

In this regard it is important to recall that in the United States conflicts erupting between "modernist" liberals and fundamentalists in the early 20th-century - though they also involved family-value issues around the "New Woman," "the flapper," and divorce, for instance-focused primarily on conflicts arising from modernists' denials of the supernatural character of events at the heart of many ordinary peoples' faith. The booklets called The Fundamentals, published in 1917, which helped launch the fundamentalist movement and give it its name, sought to defend such supernatural events like the virgin birth, the resurrection, creation, and an infallible Bible that only the Holy Spirit could have created. ${ }^{26}$

In general, the post-Enlightenment worldview has been advanced by educated elites in the West, and has often been resisted, or simply ignored, by large sectors, or subcultures in their homelands. In Africa, by contrast, Christians are not embattled by educated elites wed to both a postEnlightenment worldview and a rejection of traditional notions of gender and sexuality in family and personal life. For these reasons, African Christians are not divided into the same culture-war boxes that Americans are. While resistant to any call to legitimize homosexuality or overthrow traditional gender roles, African Christiansand Africans in general - can be quite progressive on other issues, like imagining a wider role for government and church in promoting economic development, equality and social justice.

At the same time, Africans generally uphold the everpresent possibility of the spirit-world affecting daily life. Educated westerners routinely dismiss such views disdainfully as the backward, superstitious views of the uneducated. That this represents differences in worldview rather than education, however, is evident in the fact that there is no scientific proof for the Enlightenment assumption that spiritual and material worlds do not continually interact,

\footnotetext{
${ }^{25}$ For these reasons Christian growth in Africa and elsewhere outside the West, across all denominations, is generally moving in Pentecostal or "charismatic" directions. My account of such cultural forces at work draws on the work of Andrew Walls, especially in testimony given in interviews filmed with him for this project. (Cf. video clip at vimeo.com/10825114.)

${ }^{26}$ Spirit and Flesh, p. $60 \mathrm{ff}$ and p. $180 \mathrm{ff}$
}

nor can there be. It stands beyond the scope of empirical science even though many in the educated West simply embrace it as axiomatic. However, that worldview rather than education is at work is evident in the fact that the Ghanaian Academy of Arts and Sciences, the most prestigious body of scholars in that West African nation known throughout the world for the eminent scholars it has produced, opens its monthly meetings routinely with charismatic Christian prayer. $^{27}$

Liberal elites in the West readily run the risk, by not respecting local worldviews and imposing their own, of alienating colleagues in Africa and elsewhere in the "twothirds world." In some cases, like the Anglican Communion, this can result in driving Africans into the hands of conservatives in the West. Western liberals, perhaps because of their assumptions about the separation of church and state, or their discomfort with beliefs in a "living God" (or other spirits) powerfully affecting day-to-day life, have typically failed to engage religious communities in the work they undertake in Africa. Yet, faith communities are by far the most important institution in "civil society" in most sub-Saharan African settings. Any medical work, to take one example, including work on AIDS, cannot progress without effectively engaging Africans in terms of their own worldviews seeing spiritual realities continually affecting material, bodily ones. Just as you cannot be a religious figure in Africa and not heal, you cannot be a bona fide healer and not take into account spiritual realities assumed to be involved.

African Christians often feel that the supernatural realities they recognize and deal with theologically-like demonic possession, prophesy, dreams and visions - are looked down upon with disdain by their brothers and sisters in the West. While Africans often handle such conflicts indirectly and discretely - for instance, routinely not taking visitors from sister churches in the West to central events in their own church life where such conflicts might arisesometimes such differences surface sharply. A priest sent out from the Church of England to visit sister churches in Nigeria, for instance, routinely preached in his round of appearances that Jesus' feeding of the 5,000 with five loaves and two fish was not a result of his miracle-working power, but, instead, of the power of community. After seeing him off, his Nigerian hosts wrote officials back in England, graciously thanking them for his visit, but added: "Next time, send us a Christian.",28

\footnotetext{
${ }^{27}$ Personal communication from the late Dr. Kwame Bediako, cuttingedge theologian and church historian of modern Africa.

${ }^{28}$ The latter from personal conversation with an anthropologist colleague working in Nigeria. The former comments were made by various colleagues in personal conversations with the author.
} 


\section{Differences in Moral Culture}

Finally, there are deeper, more subtle ways in which the lifestyle and worldview of educated elites in the West - and especially the United States-bring them into conflict not only with broad sectors of their fellow citizens, but also with the vast majority of people in Africa and the "twothirds world." I have in mind here conflicts arising from differences in the very shape moral culture takes in the American intelligentsia's more individualized world.

Being raised and living outside a family-based circle of people known in common means that, rather than conforming to an existing moral code shared by their elders, educated professionals must often fashion their own moralities in environments where diverse ones jostle uneasily with one another. Perhaps the only standard they might readily share among different sectors of friends, family, colleagues and schoolmates not knowing one another, is mutual tolerance for different values. They did not choose to be "moral relativists." In a sense, the lives they live call for it. Is it surprising, then, how easily they might appear as archenemies to their fellow citizens struggling to defend traditional moralities in the modern world? ${ }^{29}$

Sharon Valenti, the pastor's wife at Shawmut River, once told me that what most often revealed to her that someone was a dreaded "secular humanist" was that, "They'll say something that shows they don't believe in moral absolutes." I remember noticing how naively liberals might display such assumptions in a debate I witnessed at a school board meeting over a proposed sex education curriculum in a small mill town in Massachusetts. "I don't see how it pushes any particular values," a liberal proponent objected to conservative charges that this sex-ed curriculum did just that. "It lets individuals come up with their own." It did not occur to him that seeing values as something individuals "come up with on their own" rather than accept as givenfrom God, their parents or natural law-was itself a moral position denying that of his more traditionally minded fellow citizens around him. ${ }^{30}$

Moreover, liberal professionals, without any allencompassing family-based community around them, have to fashion their moral compass for living in more conscious, explicit ways. If this involves general moral rules, they have to be realistic ones. This was quite different from the people I met at Shawmut River. While its pastor preached "God hates divorce!" for instance, to the agreement of all listening, I noticed him and other church members helping one woman here, and another one there, divorce her husband. They advised these wives in that direction, offered them housing, helped them find an

\footnotetext{
${ }^{29}$ Spirit and Flesh, p. $191 \mathrm{ff}$

${ }^{30}$ Ibid., p. 104
}

apartment, etc. When I asked why in one particular case, people looked at me nonsensically as if I were crazy to ask. "Everyone knows," they finally explained with some exasperation, that the husband "was pissing away the family income with his drugs and snowmobile."

"Everyone knows . . ." I came to realize, was key here. It meant that in their family-based church community, as well as in the family circles that shaped their moral culture to begin with, moral judgments about any specific situation generally took place against the background of a firm bed of shared knowledge about the concrete circumstances involved. It was tacitly held and assumed to be "what everyone knows." For that reason, general rules in the abstract about divorce, or anything else, did not matter that much. It did not matter whether one clarified the rule "God hates divorce!" by adding, "except under $\mathrm{x}, \mathrm{y}$, z conditions.” In their context, "God hates divorce!" was less a hard-and-fast rule than a moral exhortation, a watchword, a saying. In these ways the fundamentalists I came to know who championed moral absolutes in black-and-white terms, were often able to routinely do sensible things - to be flexible - in ways they found difficult, even frustrating to explain. ${ }^{31}$

The underlying logic of such a moral discourse carried over, I noticed, to how members of Shawmut River used the Bible, like many of their brothers and sisters in Africa we filmed. In the first place, they learned Scripture more in talk than by reading - that is, they learned it from preaching, Sunday school teaching, Bible study groups, and in the steady flow of daily conversation. In such a densely and predominantly oral culture, the Bible functioned more as a storehouse of sayings, rather than a text to be studied and assessed for any internal inconsistencies it might contain. Given how much members knew about the concrete situations of any moral judgments they faced together, they would often know what Bible passage was relevant here and there-if someone was hurt or injured, for instance, whether "turn the other cheek" was the right response or, instead, "an eye for an eye." They would all know collectively when someone needed to be reminded of God's endless love and forgiveness, and when of God's wrath and judgment. ${ }^{32}$

The nature of such moral discourse in settings where "everyone knows" one another's business sheds light on the presumed "rigidity" and "inflexibility" liberal critics routinely attribute to fundamentalists' insistence on moral absolutes taken from Scripture and set in black-and-white terms. When seen in context such views permit more

\footnotetext{
$\overline{31}$ Ibid., pp. 196-7

${ }^{32}$ Ibid., Ch. 12. How the concrete details of any case-in-question were assembled, communicated, and brought to bear on a situation, through talk, including gossip and rumor, was of critical importance and pointed, again, to key processes of power that women in such settings enjoyed. Ibid., Ch. 21.
} 
flexible, sensible responses to human need than outsiders often imagine. It helps explain situations, to take another example, where a traditionally minded blue-collar family routinely welcomes their lesbian daughter's partner into their home for family events, embracing her with love as a special helper and confidant to the family's aging matriarch, but never speaks about their gay relationship, or let alone condones gay marriage. ${ }^{33}$

By contrast, my academic colleagues and I, in our more fragmented worlds, cannot rely on "what everyone knows" to arrive at good moral judgments. We need more general moral standards for living that give more guidance, that are more realistic, and that are crafted in more explicit and specific terms. Though we might admit that divorce is regrettable, for example, we might feel the need to recognize its moral acceptability under certain conditions. For us, moral standards take the more abstract form of general rules that we have to arrive at and embrace on our own, as individuals. They have to be viable ones, appropriate for our context and environment, rather than ones simply passed down to us.

Furthermore, the moral absolutes championed by conservatives I met held other sources of flexibility embedded in the very nature of tradition itself. The word "tradition" came into English to mean the practice of handing over a teaching or custom "especially by word of mouth or by practice without writing"- that is, without the chronological anchor of a written record. ${ }^{34}$ Tradition cannot, and does not, then, refer to the actual longevity of any moral standard or custom, but, instead, to how it has been transmitted over time.

Though change in tradition occasionally takes place in much-heralded restorations of what community members claim has fallen by the way-side, it more often and more pervasively takes place gradually, in unnoticed ways, as newly minted practices quietly assume their place next to genuinely ancient ones, coming together in an indistinguishable whole as "what we have always done time out of mind." Traditional moralities passed on through practice or by word of mouth have great scope for change and adaptation, which, nevertheless, routinely disappear "time out of mind," behind what Max Weber called "the eternal yesterday" of tradition. ${ }^{35}$ They did with "the flapper" in the wake of the 1920s, as they did with long hair on men in the 1970s (for which people had been physically attacked in the late '60s), and with conservative Christians' support for racial segregation justified by their reading of Noah's curse on Ham's descendants in Chapter 9 of Genesis. It quietly

\footnotetext{
${ }_{33}^{33}$ Personal account from a gay acquaintance.

${ }^{34}$ Ibid, p. $208 \mathrm{ff}$

${ }^{35}$ Max Weber, "Politics as Vocation," in From Max Weber, eds, H.H. Gerth and C. Wright Mills (NY: Oxford), pp. 78-79.
}

fell out of favor and then out of sight in the 1970s. ${ }^{36}$ Similarly, the traditionally held meanings any issue carries - like abortion - may vanish over time, like the issue of drinking alcohol did after dominating American politics from the Civil War to the Great Depression. ${ }^{37}$

By the same token, changes in attitudes toward homosexual relationships or abortion, for instance, may take place even while culture wars rage over moral relativism and secular humanism. This gradual, indirect and more discrete approach to change that traditional legitimation carries, it seems, was what African and Asian bishops in the Anglican Communion apparently recommended to their progressive brothers and sisters from America pressing for homosexual rights at the Lambeth Conference in 1998. However, American progressives ignored it, pressed for a vote on the issue, which was soundly defeated, and then returned home and went on to elect, in any case, the first openly gay bishop in their Episcopal Church. ${ }^{38}$ This did not sit well with their colleagues from Africa and Asia.

\section{Our Continuing Culture Wars}

America's culture wars, polarizing us into hostile camps that see each other as immoral and inhuman, continue to hold our nation in their grip. They often fragment public will and paralyze our efforts to solve pressing problems facing us as a nation, as recent congressional battles over the debt ceiling amply demonstrated. Their grip is strengthened by a persistent and seemingly intractable pattern of misperception and misunderstanding, blindnesses that persist even in expert, scholarly commentary on the subject. In one popularly acclaimed book, for instance, What's the Matter with Kansas? How Conservatives Won the Heart of America, the author ignores any appeal "pro-family" enthusiasms might have to grass-roots conservatives, and ends up portraying their "conservative backlash" simply as a "derangement" of reason resulting from conservative politicians' hoodwinking blue-color Americans into seeing "the liberal elite" rather than "big business" as their enemy - a result, he concludes, of the longstanding "penchant for

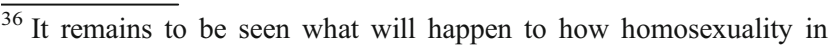
America and elsewhere will be seen and treated over time. For a fuller discussion of how tradition works within fundamentalist Christian uses of Scripture, see Spirit and Flesh, Ch. 13, p. $201 \mathrm{ff}$.

${ }^{37}$ For an exploration of this specific point, see David Frum, "What if abortion became a non-issue?" CNN Opinion, October 24, 2011, at www.cnn.com/2011/10/24/opinion/frum-abortion-issue/index.html? eref=mrss_igoogle_cnn

${ }^{38}$ This account came from personal communication with Lamin Sanneh, Professor of Divinity at Yale, who attended the conference.
} 
martyrdom" he sees in Kansas populism. ${ }^{39}$ Yet, how then should we understand the rest of the nation?

In another work, important because it was embraced by liberal Democrats as a key strategic tool in understanding conservatives and overcoming their hold on their popular base, Berkeley linguist George Lakoff sees new right conservatism springing from a "Strict Father Model" of the family, involving strict rules and painful corporal punishment, as opposed to a "Nurturant Parent" one associated with liberalism, where "love, empathy and nurturance are primary." Setting aside the question of why Lakoff thinks that liberal professors, for example, are more nurturing or loving parents than blue-collar conservativesa highly dubious proposition from my experience- - he has no way of explaining why we find one model here and another there, or of seeing them as integral parts of real-life contexts. Instead, to make his model work he ends up describing, for instance, a blue-collar worker applying a "strict father model" at home (where he spanks his child) while a "nurturant parent model" at work (where he's prounion). ${ }^{40} \mathrm{He}$ goes to lengths to explain why the "selfindulgence" liberals favor even helps them be better parents than conservatives - you have to take care of yourself, he argues, to care for others-flying in the face of the virtue of self-sacrifice and duty conservatives would emphasize. It is not hard to imagine how such an arbitrary, uncomprehending and demeaning view of "the other" did not serve liberal Democrats well in reaching conservatism's popular base over the past decade. (Instead, it was Barack Obama, with an outlook, rhetoric and sensibilities shaped largely outside the white intelligentsia - and to a considerable degree, rather, in the African-American community he settled and married into -who was able to break through and gain support from more traditionally minded, religious voters in "red" states across the country.)

Furthermore, as events in the Anglican Communion and challenges faced by global Christianity now show, America's culture wars may well flow over into the global arena, finding traction here and there. While culture-war partisans may welcome this elevation of their causes to the world stage - for the cause of "social justice" or against the immorality of "the gay agenda," for instance - others may well be concerned that the same process of polarization and paralysis

\footnotetext{
${ }^{39}$ Thomas Frank, What's the Matter with Kansas? How Conservatives Won the Heart of America (NY: Metropolitan Books, 2004)

${ }^{40}$ George Lakoff, Moral Politics: How Liberals and Conservatives Think (Chicago: University of Chicago Press, 2002), and his Don't Think of an Elephant, with an introduction by Howard Dean (White River Junction, VT: Chelsea Green Publishing, 2004). Though Lakoff gets some mileage here and there from his model, for instance, by noting the importance in conservative discourse of a "system of rewards and punishments," he never connects this with the ethic of reciprocity governing helping relationships, or sees such elements as integral parts of actual social relationships.
}

rooted in misunderstanding and misperception may hinder global efforts to solve pressing problems. ${ }^{41}$

If America's liberal intelligentsia is to play a constructive role either locally or globally, it must look beyond its own taken-for-granted assumptions about family and personal life, and beyond its own worldview naively yet deeply configured by such assumptions and by its post-Enlightenment outlook. It must do that simply in order to understand the lives, sensibilities, circumstances and outlook of many of its fellow citizens. If it cannot understand them, how can it lead or even appeal to them? That includes not only liberals' enemies at home, many of whom have come to detest them as the favored laughing stock of recognizably popular conservative talk-show hosts, but also those many peoples in the "two-thirds world" whose lives differ from their own in quite similar ways. To assume and even vaunt their own values and worldview as the only reasonable ones, over and against those they dismiss as irrational, narrow-minded, rigid or crazy, stands to alienate them from the majority of humankind, as they already have to large portions of their fellow Americans.

James M. Ault, Jr. is an award-winning documentary filmmaker and author educated in the social sciences at Harvard and Brandeis (Ph.D. in Sociology). His film Born Again: Life in a Fundamentalist Baptist Church was broadcast as a national primetime special on PBS and around the world and won a Blue Ribbon at the American Film Festival. His book on that project, Spirit and Flesh (Knopf 2004), was named one of the 5 best non-fiction books of the year by The Christian Science Monitor and called by The Washington Post "The best single-volume explanation of why American fundamentalist Christianity thrives among certain people ... and why it will not die out," $\mathrm{He}$ is completing a documentary series on African Christianity filmed in Ghana, Zimbabwe and the United States, and writing a book on that project that will have, in its e-book version, links to video embedded in the text. This article is based on a paper given as part of a workshop on the future of social conservatism, directed by Jon Shields and sponsored and funded by the Henry Salvatori Center for the Study of Individual Freedom in the Modern World at Claremont McKenna College, May 20-21, 2011.

\footnotetext{
${ }^{41}$ For their part, American conservatives showed themselves capable of misreading how their initiatives might play out in Africa, when American evangelicals recently fanned fires against "the homosexual agenda" in Uganda, leading to proposed legislation making homosexual acts, under certain conditions, punishable by death. The proposed legislation was eventually abandoned. The subsequent murder of a Ugandan gay rights activist, David Kato, was first reported as a result of that American-sponsored campaign. Jeffrey Gettleman, "Ugandan Who Spoke Up for Gays is Beaten to Death," NY Times, January 27, 2011. It subsequently came to light, however, that Kato was murdered by a male sex worker staying with him who felt Kato had not paid him what he was due. (Whether the climate created in part by that campaign contributed to that act is another question.) "Male Prostitute killed Uganda gay activist," AFP, Feb. 3, 2011. Andrew Bagala, "Gay activist suspected killer arrested". Daily Monitor, Feb. 3, 2011. At: google.com/hostednews/afp/article/ALeqM5ihVH6Ahnbnhdo3Cq rEDT $3 \mathrm{mCBknKg}$ ? docId=CNG.9057 dbf 4 f3 db 02 f9 2 ea 392 16b26eb623.8a1
} 